\title{
Investigation of the protective effects of melatonin, amifostine (WR-2721), and N-acetylcysteine on radiotherapy-induced uterine tissue injury in rats
}

\author{
U. Seker $^{1}$, A. Aktas ${ }^{1}$, Y. Nergiz ${ }^{1}$, S.B. Zincircioglu², M.A. Ketani3 \\ ${ }^{1}$ Dicle University, Faculty of Medicine, Department of Histology and Embryology, Diyarbakir, Turkey. \\ ${ }^{2}$ Dicle University, Faculty of Medicine, Department of Radiation Oncology, Diyarbakir, Turkey. \\ ${ }^{3}$ Dicle University, Faculty of Veterinary Medicine, Department of Histology and Embryology, Diyarbakir, Turkey.
}

\section{- Original article}

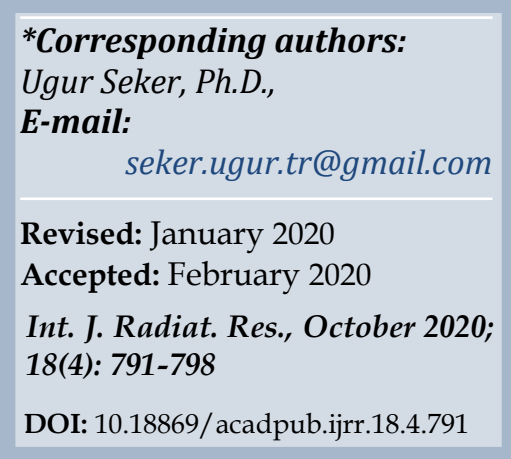

\begin{abstract}
Background: The aim of this study was to investigate the protective potency of melatonin, amifostine (WR-2721), and N-acetylcysteine (NAC) when administered intraperitoneally (i.p.) $15 \mathrm{~min}$ before 10-Gy single-fraction radiotherapy. Materials and Methods: In this study, 35 female Sprague Dawley rats were divided into five groups of seven rats each. The rats in the control group did not receive any treatments. Rats in the radiotherapy, melatonin, amifostine, and NAC groups underwent abdomino-pelvic irradiation with 10-Gy single fraction gamma $(\gamma)$ irradiation. Melatonin $50 \mathrm{mg} /$ $\mathrm{kg}$, amifostine $200 \mathrm{mg} / \mathrm{kg}$, and NAC $500 \mathrm{mg} / \mathrm{kg}$ were i.p. administered to the rats $15 \mathrm{~min}$ before irradiation. Animals were sacrificed $48 \mathrm{~h}$ after irradiation. Uterus samples were collected and, routine histopathological tissue processing was performed. Sections from tissue samples were stained with H\&E and analyzed with the terminal deoxynucleotidyl transferase dUTP nick end labelling method (TUNEL assay). Results: Severe morphological degenerations and increases in the apoptotic index (Al) were observed in the radiotherapy group. Tissue protection and Al reduction were observed in the amifostine and NAC groups. Melatonin was more effective than amifostine and NAC. Morphological damage was almost completely repaired, and the AI of the melatonin group was quite similar to that of the control group. Conclusion: This experiment failed to determine a more successful administration technique of amifostine. The protective effects of amifostine and NAC were similar. Melatonin was more successful than these two drugs, and might be an alternative to amifostine when time, dose, or adverse effect constraints are encountered.
\end{abstract}

Keywords: Radiotherapy, uterus, apoptosis, melatonin, amifostine, NAC.

\section{INTRODUCTION}

The aim of radiotherapy is to provide the highest possible dose to the tumor without affecting normal tissue. However, the radioresistance of tumor cells to administered doses in a fractionated regimen leads to limitations in cures $(1,2)$. Fractional radiotherapy controls tumors short-term and provides palliative treatment, but single-fraction radiotherapy doses aim to increase the chances of a cure (3). Radiotherapy leads to acute or chronic adverse effects, which are known as normal tissue injury (4-6). The amount of normal tissue injury is directly proportional to the radiotherapy dose, and single fraction 10-Gy radiotherapy is a common practice due to symptom alleviation, tolerability, and tumor responsiveness in patients (7-9). Skin irritation, DNA damage, apoptosis induction, vascular permeability, edema, vascular endothelial cell swelling, the adhesion and infiltration of 
lymphocytes, necrosis, death and secondary cancer formation may be listed as acute or chronic side effects of radiotherapy (10,11). In addition, radiotherapy leads to ovarian failure, premature menopause, and unhealthy pregnancy in premenopausal women long after treatment $(12,13)$.

Natural or synthetic chemical, with antioxidant potency can effectively alleviate or repair normal tissue injury. One of these chemicals is melatonin (N-acetyl-5methoxytryptamine), which is secreted by the pineal gland and regulates the sleep-wake cycle, pubertal development, and seasonal adaptation. Melatonin effectively reduces toxicity, cellular DNA fragmentation, and lipid peroxidation (14). The free radical scavenger potency of melatonin suggests that it might be used as a reliable protective drug in radiotherapy.

Numerous studies reported the effectiveness of different types of synthetic chemicals, in addition to antioxidant hormones, such as melatonin, to protect normal tissues. Amifostine is one of these synthetic chemicals, and it is a prodrug developed by the U.S. Army's Anti-Radiation Drug Development Program. Amifostine is an inorganic thiophosphate that is rapidly converted in vivo to its active form, WR-1065, by alkaline phosphatase in vascular endothelial cells (15). Some studies have indicated that amifostine can selectively protect normal tissue morphology from radiotherapy (16), but tumors do not benefit from the protective effects of amifostine (17). However, the amount of time that has elapsed between drug administration and radiotherapy is crucial due to the time required for drug metabolism, and amifostine may lead to severe adverse effects (18).

Another synthetic radioprotective drug is NAC. It serves as a mucoregulator with the lowest toxicity in natural cysteine. The radioprotective profile of NAC includes the reduction of the malondialdehyde volume, DNA fragmentation, and lipid peroxidation in response to radiotherapy (19). In this study we aimed to investigate the protective effects of three different drugs on uterine tissue injury in single fraction 10-Gy radiotherapy in rats.

\section{MATERIALS AND METHODS}

\section{Animals}

All experimental procedures were performed with the permission of the Local Animal Experiments Ethics Committee of Sabahattin Payzın Experimental Animal Center from the University of Dicle (approval number: 2012/35). Thirty-five adult 8-10-week-old 220-250-g female Sprague-Dawley rats were divided into five groups of seven rats each. The rats were housed in polycarbonate cages at room temperature $\left(21 \pm 3^{\circ} \mathrm{C}\right)$ and $50 \pm 5 \%$ humidity with a 12-h light-dark cycle. They were fed a laboratory standard pellet diet, and ad libitum water was provided. The experiment was performed after a stabilization period.

\section{Experimental design}

A vaginal smear of the rats was evaluated, and rats in the diestrus phase were included in the experiment. Smear tests were performed until each group included seven animals. The control group did not receive any treatments. The radiotherapy, melatonin, amifostine and NAC groups were exposed to external single fraction 10-Gy abdomino-pelvic $\gamma$-radiation at a constant dose of $1.25 \mathrm{~Gy} / \mathrm{min}$ using an Alcyon II $\mathrm{Co}^{60}$ (CGR, MeV, France) teletherapy unit. Radiotherapy was performed in a $30 \times 30 \mathrm{~cm}^{2}$ square area at an $80-\mathrm{cm}$ distance from of the medial abdominopelvic region of the rats. Melatonin $25 \mathrm{mg} / \mathrm{kg}$ (Sigma-Aldrich, USA), amifostine $200 \mathrm{mg} / \mathrm{kg}$ (Ethyol, Er-kim ilac, Turkey) and NAC $500 \mathrm{mg} / \mathrm{kg}$ (Asist Ampul, Turkey) were intraperitoneally (i.p.) administered to the rats $15 \mathrm{~min}$ before irradiation. All rats were sacrificed $48 \mathrm{~h}$ after the experiment with intracardiac blood withdrawal and uterus tissue collection.

\section{Histopathological examination}

Uterus tissue samples were collected in neutral buffered $10 \%$ formalin, and a routine tissue processing protocol was performed. 
Under a rotary microtome, $5-\mu \mathrm{m}$ thick sections were taken from the paraffin blocks and placed on adhesive slides. Sections were stained with hematoxylin and eosin (H\&E) and were analyzed with the TUNEL assay. Stained samples were analyzed and micrographs were taken with a Zeiss Axio Imager A2 (Zeiss Co. Germany) light microscope.

\section{TUNEL assay and statistical analysis}

To evaluate the apoptotic index (AI), an In Situ Cell Death Detection Kit-AP (Roche Diagnostics Corp.) was used. The TUNEL assay protocol was performed according to the manufacturer's instructions. The AI of the luminal epithelium, stromal cells and uterine gland cells of uterus samples were evaluated separately. During the luminal epithelium evaluation, cells were counted starting from a randomly selected point. Cells were marked with a positive or negative signal until there was a total of 100 cells. When marking was completed, the positive cell rate was manually calculated from the total 100 counted cells. The positive luminal epithelium cell rate was calculated in each tissue sample according to this method. During the stromal cell AI evaluation, the stromal region of uterine tissue was divided into 48 equal squares. Stromal cell counting started from the upper left square. Cells on the border lines were not included. Cells were marked with either a positive or negative signal, and marking was complete when 100 stromal cells were marked. Stromal cell counting was performed on three randomly selected regions of each uterine tissue sample, and the rate of positive signal in the total 300 counted cells was calculated as the positive signal rate. The uterine gland cell AI was evaluated by randomly selecting three uterine glands and marking gland cells as positive or negative. The positive signal rate was manually calculated from the total cell counts of the three uterine glands in each tissue section. TUNEL assay analyses were performed with Image J Software (LOCI, University of Wisconsin), and statistical analyses were performed with SPSS 21.0 (IBM) with a nonparametric Kruskal Wallis test. For multiple comparisons, $\mathrm{p}<0.05$ was considered significant, and the results were expressed as mean \pm standard error of the mean (SEM).

\section{RESULTS}

\section{Histopathologic results}

Normal morphology was observed in the control group sections. Normal uterine stroma, luminal epithelium, and uterine gland morphology were observed. In the radiotherapy group, luminal epithelium desquamation and mononuclear cell infiltration in the stromal region were observed. Dilation in the capillaries and hemorrhage in the vascular structure were detected. The uterine gland lumen was irregular, and minimal proliferation was seen in the uterine glands. No morphological changes were observed in the myometrium of any groups, except congestion and vasodilation in the stratum vasculare of the radiotherapy group. The uterine luminal epithelium integrity was protected in the melatonin group, and normal endometrial glands were observed. We observed numerous lymphocyte infiltrations in the uterine stroma. The vascular structures of the stroma and morphology of the stratum vasculare were similar to those of the control group. In the amifostine group, the uterine gland damage was limited. Minimal desquamation in the luminal epithelium and lymphocyte infiltration was detected. The damaged vascular structure in the endometrial capillaries, uterine glands, and stratum vasculare was reduced significantly when compared with the damage in the radiotherapy group. In the sections of the NAC group, the luminal epithelium had minimal desquamation. Edema and lymphocyte infiltration in the sub-epithelial region of the endometrium were observed (figure 1).

\section{Results of the TUNEL assay and statistical analysis}

Micrograps and statistical analysis results for TUNEL assay were shown in table 1 , figure $2 \&$ figure 3. The control group had few AI values with limited positive signal rates on the luminal epithelium, stromal cells, and uterine gland cells. There was a significant increase in the AI of the 
radiotherapy group for the luminal epithelium, stromal cells and uterine gland cells. The AI values of the amifostine, melatonin, and NAC groups significantly decreased for the luminal epithelium cells when compared with that of the radiotherapy group (figure 2 ). In the melatonin and NAC groups, the AI of the stromal cells was similar to that of the control group. The AI of the amifostine stromal cells decreased significantly when compared with that of the radiotherapy group. However, it was significantly higher than that of the control, melatonin, and NAC groups. The AI values of the uterine gland cells of the melatonin and amifostine groups were similar to that of the control group. There was a significant decrease in the AI of the uterine gland cells of the NAC group when compared with the control group. However, the AI of the uterine gland cells of the NAC group was significantly lower than that of the radiotherapy group but higher than that of the control, melatonin, and amifostine groups.

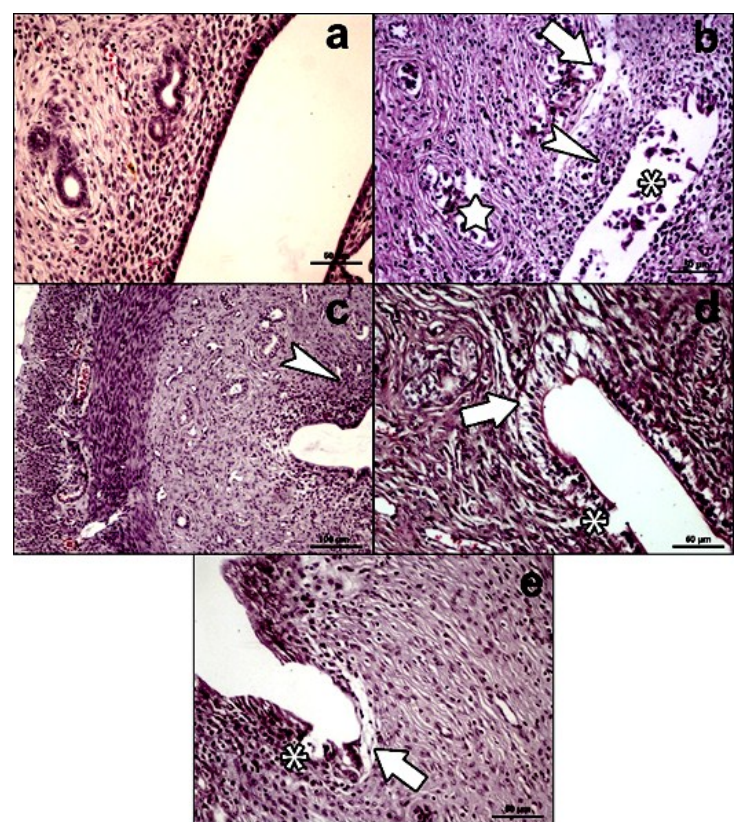

Figure 1. Micrographs of uterine tissue samples. a) Control group; normal uterinal tissue morphology observed, b) Radiotherapy group; luminal epithelium $(*)$ and uterinal gland cells («), subepithelial edema (thick arrow) and lymphocyte infiltration (arrowhead), c) Melatonin group; normal uterine stroma (arrowhead), d) Amifostine group; luminal epithelium desquamation and vacuolisation $\left({ }^{*}\right)$, subepithelial edema (thick arrow), e) NAC group; luminal epithelium desquamation $\left({ }^{*}\right)$, subepithelial edema (thick arrow). (Staining: H\&E, Bar: 50 $\mu \mathrm{m}$ at $\mathrm{a}, \mathrm{b}, \mathrm{d}, \mathrm{e}$, and $100 \mu \mathrm{m}$ at c).
Table 1. TUNEL assay results.

\begin{tabular}{|c|c|c|c|}
\hline Group & $\begin{array}{c}\text { Luminal } \\
\text { epithelium } \\
\text { Al (\%) }\end{array}$ & $\begin{array}{c}\text { Stromal } \\
\text { cells AI (\%) }\end{array}$ & $\begin{array}{c}\text { Uterinal gland } \\
\text { cells Al (\%) }\end{array}$ \\
\hline Control & $2.6 \pm 0.68^{\mathrm{a}}$ & $2.9 \pm 0.39^{\mathrm{c}}$ & $2.3 \pm 0.56^{\mathrm{f}}$ \\
\hline Radiotherapy & $18.7 \pm 3.61^{\mathrm{b}}$ & $15.6 \pm 2.71^{\mathrm{e}}$ & $28.2 \pm 5.37^{\mathrm{h}}$ \\
\hline Melatonin & $4.0 \pm 1.32^{\mathrm{a}}$ & $2.7 \pm 0.79^{\mathrm{c}}$ & $4.0 \pm 0.79^{\mathrm{f}}$ \\
\hline Amifostine & $7.0 \pm 1.02^{\mathrm{a}}$ & $9.3 \pm 1.93^{\mathrm{d}}$ & $16.6 \pm 3.77^{\mathrm{g}}$ \\
\hline N-acetylcysteine & $5.0 \pm 1.92^{\mathrm{a}}$ & $4.6 \pm 0.93^{\mathrm{c}}$ & $8.9 \pm 1.13^{\mathrm{fg}}$ \\
\hline
\end{tabular}

Values with different superscripts in the same column are significantly different (ab: $p<0.01$; cde: $p<0.001$; fgh: $p<0.0001$ ).

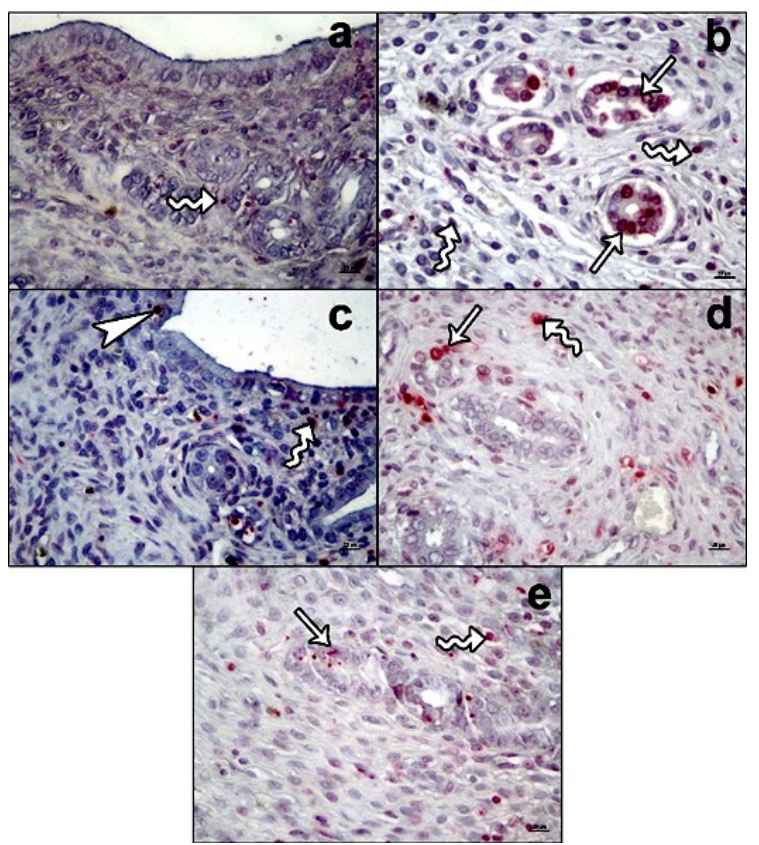

Figure 2. TUNEL assay micrographs of uterine tissue samples. a) Control group; positive signals in stroma (curved arrow), b) Radiotherapy group; positive signals in stromal cells (curved arrow) and uterinal gland cells (arrow), c) Melatonin group; a small number of positive signals in stromal (curved arrow) and luminal epithelium (arrowhead), d) Amifostine group; positive signals in stromal cells (curved arrow) and uterinal gland cells (arrow) (Staining: TUNEL assay, Bar: $20 \mu \mathrm{m}$ ). e) NAC group; positive signals in stromal (curved arrow) and uterine gland cells (arrow). (Staining: TUNEL assay, Bar: $20 \mu \mathrm{m}$ ).

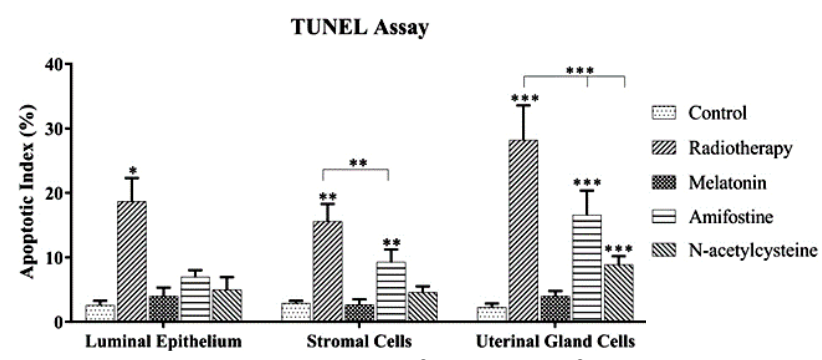
Figure 3. TUNEL assay results of groups. Different supersctipts on each column shows significantly difference between groups $\left({ }^{*} ; p<0.01,{ }^{* *} ; p<0.001,{ }^{* * *} ; p<0.0001\right)$.

Int. J. Radiat. Res., Vol. 18 No. 4, October 2020

\section{4}




\section{DISCUSSION}

The results of this study indicate that the three different chemicals used successfully alleviated or repaired radiotherapy-induced morphological degenerations and apoptosis to varying degrees. The protective effect of melatonin, amifostine, and NAC on normal tissue has been discussed in numerous studies, but this is the first study to investigate the protective effects of different chemicals on the degenerative effects of radiotherapy in the uterus.

Radiotherapy shows its degenerative effects on cells and tissues with either DNA interaction or toxic free radical production. However, more than two-thirds of its degenerative effects result from free radicals (20). Hence, a successful radioprotective drug should have an antioxidant profile that goes beyond DNA protection. Radiotherapy is expected to kill cancer cells. However, tumor surrounding tissue or distal organs may be exposed to the degenerative effects of radiotherapy (i.e., undergo normal tissue injury). Normal tissue injury is characterized by organ dysfunction, and it is a cure-limiting property of radiotherapy. Studies on radiotherapy-induced uterine tissue injury are extremely limited.

Numerous studies have been performed to determine the most successful adjuvant to avoid the degenerative effects and toxicity of radiotherapy treatment. The morphological degenerative effects of radiotherapy on the uterus show the ability of radiotherapy to cause some morphological damage and induce apoptosis. Irradiated uterine cells express fewer mitosis-processing proteins $(21,22)$. Interestingly, related studies have reported that the most affected site of uterine tissue is the luminal epithelium followed by the uterine glands. These degenerations manifest as vacuolation in the luminal epithelium, increased apoptotic protein expression, and TUNEL assay positivity, which are strong signs of DNA fragmentation and apoptosis (23). Our results are consistent with those of previous studies. However, we observed more severe degenerations and an increase in TUNEL positivity in all parts of the uterine tissue. We estimate that these findings may be a result of a higher radiotherapy dose. The AI provides information on the radiosensitivity of cells (24). The AI results of this study indicate that the luminal epithelium might be the most radiosensitive region of the uterine tissue.

Since the introduction of radiotherapy in cancer treatment, adverse effects have been a limitation of treatment. Fractioned radiotherapy is used as a way to avoid this limitation, but low doses of radiation may lead to tumor survival and may not go beyond tumor control and palliative treatment. Recently, however, critical evidence indicates that high-dose radiotherapy (i.e., above 8-10 Gy) may be more successful than fractional radiotherapy in tumor treatment. High -dose single-fraction radiotherapy induces tumor endothelial apoptosis, depletes the tumor vasculature, and directly kills tumor cells $(25,26)$. These results increase the significance of the radioprotective drug activity, dose, and administration route.

Amifostine is standardly administered as an intravenous infusion to rapidly reach the maximal tissue concentration. Studies have demonstrated that amifostine selectively protects normal tissues, but it has some severe adverse effects that may lead to discontinuation of radiotherapy (27). With intraperitoneal administration, a maximal tissue concentration of amifostine is observed between 10 and $30 \mathrm{~min}$ (28). Numerous studies have discussed the protective potency of amifostine. Some of these studies reported failures of this drug (29), but most of them reported successful results when administered at doses of $200 \mathrm{mg} / \mathrm{kg}$ via the intraperitoneal route (30-33). In addition, the failures were believed to be a result of low-dose administration. Our results were consistent with the studies that reported success with amifostine in radiotherapy, but more studies are required to further determine the protective potency of amifostine. In a previous study, the radioprotective potency of NAC was demonstrated to be as successful as that of amifostine (34). In addition to being radioprotective, NAC has been reported to be cytoprotective when administered at doses of 
$500 \mathrm{mg} / \mathrm{kg}$ via the intraperitoneal route (35). However, different doses of NAC have successfully reduced apoptosis and tissue injury when administered i.p. prior to radiotherapy [36]. These results indicate that our study and previous studies are consistent because we observed a significant reduction in apoptosis and tissue injury in the NAC group compared with the radiotherapy group. Our results showed that the protective potency of amifostine and NAC were similar, as reported in previous studies

Radioprotective drugs aim to alleviate normal tissue injury and reduce tumor resistance while providing radiosensitivity to tumor cells (37). In recent years, it was believed that melatonin might be used as a radioprotective drug in radiotherapy. In addition, melatonin was reported to sensitize tumor cells to radiotherapy (38). Hence, due to low toxicity and selective radioprotective activity, melatonin has been reported and discussed in many studies (39). It was reported to have substantial free radical scavenging activity that protects against tissue injury and apoptosis (40-42). In addition, both 25 and $50 \mathrm{mg} / \mathrm{kg}$ doses of intraperitoneal melatonin $15 \mathrm{~min}$ before radiotherapy protected bone structure. This study indicated that melatonin and amifostine similarly protected bone structure in radiotherapy (43).

We observed that melatonin protected against uterine tissue injury and significantly reduced the AI. Moreover, the tissue injury level and AI of the melatonin group was similar to those in the control group, and melatonin was more successful when compared with amifostine and NAC. However, radioprotection is very broad topic, and these drugs should be evaluated in new, well-designed, sufficiently powered, experimental and clinical trials.

\section{CONCLUSIONS}

This is the first study to explore radiotherapy -induced uterine tissue damage and the protective potency of different substances in detail. Our results demonstrate that both amifostine and NAC alleviated morphological degenerations from radiotherapy, but melatonin was more successful. We estimate that amifostine may require more doses to reach maximal protection or the current dose may require more time to undergo sufficient metabolism after i.p. administration. In addition, melatonin might be an alternative to amifostine in clinics.

\section{ACKNOWLEDGEMENT}

This study was financed by University of Dicle, Scientific Research Projects Coordination Unit (Grant no: 12-TF-99).

Authors thank to Dr. Berna Sozen from University of Cambridge and Professor Necdet Demir from University of Akdeniz for providing necessary support.

\section{Conflicts of interest: Declared none.}

\section{REFERENCES}

1. Peters LJ, Withers HR, Thames HD, Fletcher GH (1982) Keynote address-The problem: Tumor radioresistance in clinical radiotherapy. Int J Radiat Oncol Biol Phys, 8(1): 101 $-108$.

2. West CL, Davidson S, Hendry J, Hunter R (1991) Prediction of cervical carcinoma response to radiotherapy. The Lancet, 338(8770): 818.

3. Ahmad SS, Duke S, Jena R, Williams MV, Burnet NG (2012) Advances in radiotherapy. BMJ (Clinical research ed), 345: e7765.

4. Barnett GC, West CM, Dunning AM, Elliott RM, Coles CE, Pharoah PD, Burnet NG (2009) Normal tissue reactions to radiotherapy: towards tailoring treatment dose by genotype. Nature Reviews Cancer, 9(2): 134-142.

5. Bentzen SM (2006) Preventing or reducing late side effects of radiation therapy: radiobiology meets molecular pathology. Nature Reviews Cancer, 6(9): 702-713.

6. Jereczek-Fossa BA, Jassem J, Badzio A (2002) Relationship between acute and late normal tissue injury after postoperative radiotherapy in endometrial cancer. Int $J$ Radiat Oncol Biol Phys, 52(2): 476-482.

7. Bezjak A, Dixon P, Brundage M, Tu DS, Palmer MJ, Blood $P$, Grafton C, Lochrin C, Leong C, Mulroy L (2002) Random-

Int. J. Radiat. Res., Vol. 18 No. 4, October 2020 
ized phase III trial of single versus fractionated thoracic radiation in the palliation of patients with lung cancer (NCIC CTG SC. 15). Int J Radiat Oncol Biol Phys, 54(3): 719728.

8. Maj JG, Paris F, Haimovitz-Friedman A, Venkatraman E, Kolesnick R, Fuks Z (2003) Microvascular function regulates intestinal crypt response to radiation. Cancer Research, 63(15): 4338-4341.

9. Onsrud M, Hagen B, Strickert T (2001) 10-Gy single-fraction pelvic irradiation for palliation and life prolongation in patients with cancer of the cervix and corpus uteri. Gynecologic oncology, 82(1): 167-171.

10. Morton LM, Swerdlow AJ, Schaapveld M, Ramadan S, Hodgson DC, Radford J, van Leeuwen FE (2014) Current knowledge and future research directions in treatmentrelated second primary malignancies. European Journal of Cancer Supplements, 12(1): 5-17.

11. Peña LA, Fuks Z, Koksnick R (1997) Stress-induced apoptosis and the sphingomyelin pathway. Biochem Pharmacol, 53(5): 615-621.

12. Critchley HO and Wallace WHB (2005) Impact of cancer treatment on uterine function. JNCl Monographs, 2005 (34): 64-68.

13. Meirow $D$ and Nugent $D$ (2001) The effects of radiotherapy and chemotherapy on female reproduction. Human Reproduction Update, 7(6): 535-543.

14. Ündeğer Ü, Giray B, Zorlu AF, Öge K, Baçaran N (2004) Protective effects of melatonin on the ionizing radiation induced DNA damage in the rat brain. Experimental and Toxicologic Pathology, 55(5): 379-384.

15. Smoluk GD, Fahey RC, Calabro-Jones PM, Aguilera JA, Ward JF (1988) Radioprotection of cells in culture by WR2721 and derivatives: form of the drug responsible for protection. Cancer Research, 48(13): 3641-3647.

16. Vesna J, Danica J, Kamil K, Viktorija DS, Silva D, Sanja T, Ivana B, Zoran S, Zoran M, Dubravko B (2016) Effects of fullerenol nanoparticles and amifostine on radiationinduced tissue damages: Histopathological analysis. Journal of Applied Biomedicine, 14(4): 285-297.

17. Koukourakis MI (2003) Amifostine: is there evidence of tumor protection? Seminars in Oncology, 30: 18-30.

18. Brizel DM, Wasserman TH, Henke M, Strnad V, Rudat V, Monnier A, Eschwege F, Zhang J, Russell L, Oster W (2000) Phase III randomized trial of amifostine as a radioprotector in head and neck cancer. Journal of Clinical Oncology, 18(19): 3339-3345.

19. Mansour HH, Hafez HF, Fahmy NM, Hanafi N (2008) Protective effect of $\mathrm{N}$-acetylcysteine against radiation induced DNA damage and hepatic toxicity in rats. Biochemical Pharmacology, 75(3): 773-780.

20. Mozdarani H (2012) Biological complexities in radiation carcinogenesis and cancer radiotherapy: impact of new biological paradigms. Genes, 3(1): 90-114.

21. Carabajal E, Massari N, Croci M, Lamas DM, Prestifilippo J, Ciraolo P, Bergoc R, Rivera E, Medina V (2012) Radioprotective potential of histamine on rat small intestine and uterus. European journal of histochemistry: EJH, 56(4): 302-310.

Int. J. Radiat. Res., Vol. 18 No. 4, October 2020
22. Mahran YF, El-Demerdash E, Nada AS, El-Naga RN, Ali AA, Abdel-Naim AB (2015) Growth hormone ameliorates the radiotherapy-induced ovarian follicular loss in rats: impact on oxidative stress, apoptosis and IGF-1/IGF-1R axis. PloS one, 10(10): e0140055.

23. Said RS, Nada AS, El-Demerdash E (2012) Sodium selenite improves folliculogenesis in radiation-induced ovarian failure: a mechanistic approach. PloS one, 7(12): e50928.

24. Bhosle SM, Huilgol NG, Mishra KP (2005) Apoptotic index as predictive marker for radiosensitivity of cervical carcinoma: Evaluation of membrane fluidity, biochemical parameters and apoptosis after the first dose of fractionated radiotherapy to patients. Cancer Detection and Prevention, 29(4): 369-375.

25. Garcia-Barros M, Paris F, Cordon-Cardo C, Lyden D, Rafii S, Haimovitz-Friedman A, Fuks Z, Kolesnick R (2003) Tumor response to radiotherapy regulated by endothelial cell apoptosis. Science, 300(5622): 1155-1159.

26. Yamada Y, Bilsky MH, Lovelock DM, Venkatraman ES, Toner S, Johnson J, Zatcky J, Zelefsky MJ, Fuks Z (2008) Highdose, single-fraction image-guided intensity-modulated radiotherapy for metastatic spinal lesions. Int J Radiat Oncol Biol Phys, 71(2): 484-490.

27. Rades D, Fehlauer F, Bajrovic A, Mahlmann B, Richter E, Alberti W (2004) Serious adverse effects of amifostine during radiotherapy in head and neck cancer patients. Radiotherapy and Oncology, 70(3): 261-264.

28. Van der Vijgh $W$ and Korst A (1996) Amifostine (Ethyol ${ }^{\circledR}$ ): pharmacokinetic and pharmacodynamic effects in-vivo. European Journal of Cancer, 32: S26-S30.

29. Mitsuhashi N, Takahashi I, Takahashi M, Hayakawa K, Niibe $H$ (1993) Clinical study of radioprotective effects of amifostine (YM-08310, WR-2721) on long-term outcome for patients with cervical cancer. Int J Radiat Oncol Biol Phys, 26(3): 407-411.

30. Caloglu M, Yurut-Caloglu V, Durmus-Altun G, Oz-Puyan F, Ustun F, Cosar-Alas R, Saynak M, Parlar S, Turan FN, Uzal C (2009) Histopathological and scintigraphic comparisons of the protective effects of I-carnitine and amifostine against radiation-induced late renal toxicity in rats. Clinical and Experimental Pharmacology and Physiology, 36(5-6): 523530.

31. Tokatli F, Uzal C, Doganay L, Kocak Z, Kaya M, Ture M, Kurum T, Alkaya F, Karadag H, Kutlu K (2004) The potential cardioprotective effects of amifostine in irradiated rats. Int J Radiat Oncol Biol Phys, 58(4): 1228-1234.

32. Uzal C, Durmus-Altun G, Caloglu M, Ergülen A, Altaner S, Yigitbasi NO (2004) The protective effect of amifostine on radiation-induced acute pulmonary toxicity: Detection by 99mTc-DTPA transalveolar clearances. Int J Radiat Oncol Biol Phys s, 60(2): 564-569.

33. Vujaskovic Z, Feng QF, Rabbani ZN, Samulski TV, Anscher MS, Brizel DM (2002) Assessment of the protective effect of amifostine on radiation-induced pulmonary toxicity. Experimental Lung Research, 28(7): 577-590.

34. Kilciksiz S, Demirel C, Ayhan SE, Erdal N, Gurgul S, Tamer L, Ayaz L (2011) N-acetylcysteine ameliorates nitrosative 
stress on radiation-inducible damage in rat liver. $J B U O N$, 16(1): 154-159.

35. Abdelrahman AM, Al Salam S, AIMahruqi AS, Al Husseni IS, Mansour MA, Ali BH (2010) N-acetylcysteine improves renal hemodynamics in rats with cisplatin-induced nephrotoxicity. Journal of Applied Toxicology, 30(1): 15-21.

36. Gao W, Liang JX, Ma C, Dong Jy, Yan Q (2017) The protective effect of $\mathrm{N}$-acetylcysteine on ionizing radiation induced ovarian failure and loss of ovarian reserve in female mouse. BioMed Research International, 2017: 1-11.

37. Allison R and Dicker A (2014) Minimizing morbidity in radiation oncology: a special issue from Future Oncology. Future Oncology, 10(15): 2303-2305.

38. Vasin MV and Ushakov IB (2014) Comparative efficacy and the window of radioprotection for adrenergic and serotoninergic agents and aminothiols in experiments with small and large animals. Journal of Radiation Research, 56(1): 110.

39. Farhood B, Goradel N, Mortezaee K, Khanlarkhani N, Salehi E, Nashtaei M, Mirtavoos-Mahyari H, Motevaseli E, Shabeeb D, Musa A (2019) Melatonin as an adjuvant in radiotherapy for radioprotection and radiosensitization. Clinical and Translational Oncology, 21(3): 268-279.
40. Fernández-Gil B, Moneim AEA, Ortiz F, Shen $Y-Q$, SotoMercado V, Mendivil-Perez M, Guerra-Librero A, AcuñaCastroviejo D, Molina-Navarro MM, García-Verdugo JM (2017) Melatonin protects rats from radiotherapy-induced small intestine toxicity. PLoS One, 12(4): e0174474.

41. Guney Y, Hicsonmez A, Uluoglu C, Guney H, Ozel Turkcu U, Take G, Yucel B, Caglar G, Bilgihan A, Erdogan D (2007) Melatonin prevents inflammation and oxidative stress caused by abdominopelvic and total body irradiation of rat small intestine. Brazilian Journal of Medical and Biological Research, 40(10): 1305-1314.

42. Tahamtan R, Monfared AS, Tahamtani Y, Tavassoli A, Akmali M, Mosleh-Shirazi MA, Naghizadeh MM, Ghasemi D, Keshavarz M, Haddadi GH (2015) Radioprotective effect of melatonin on radiation-induced lung injury and lipid peroxidation in rats. Cell Journal (Yakhteh), 17(1): 111120.

43. Çakir ZÜ, Demirel C, Kilciksiz SC, Gürgül S, Zincircioğlu SB, Erdal N (2016) Melatonin can ameliorate radiationinduced oxidative stress and inflammation-related deterioration of bone quality in rat femur. Inflammation, 39(3): 1134-1140. 